\title{
GAME REAL TIME ACTION RPG ONLINE BERBASIS FLASH: ALTERNATIF BERMAIN GAME DENGAN SPESIFIKASI PERANGKAT KERAS MINIMAL
}

\author{
Paulus Adi Purnomo; Budi Prasetyo; Elidjen \\ Computer Science Department, School of Computer Science, Binus University \\ Jln. K.H. Syahdan No.9, Palmerah, Jakarta Barat 11480 \\ elidjen@binus.edu
}

\begin{abstract}
Various games are available for a variety of community as one means of entertainment which is getting more popular these days. However, sometimes several games can not be played on computer due to insufficient hardware specifications support. This situation developed the making of ChainKiller Game, a Flash based real time action RPG online game to provide an alternative as well as interactive and interesting game with a minimum hardware specification. The sequential linear process model is used to develop the overall game. Besides, a literature study was implemented to enrich the insight to develop the interesting mini game. The realtime action RPG online game which is based on Flash can be easyly used with minimum hardware specification.
\end{abstract}

Keywords: game, real time, RPG, online, Flash, minimum hardware specification

\begin{abstract}
ABSTRAK
Berbagai game tersedia bagi berbagai kalangan masyarakat untuk dimainkan sebagai salah satu sarana hiburan yang belakangan ini semakin popular dan digandrungi. Tetapi tidak jarang game yang ingin dimainkan tidak bisa terealisasikan karena spesifikasi perangkat keras yang dibutuhkan tidak mencukupi kebutuhan yang diperlukan oleh game tersebut. Hal inilah yang melatarbelakangi dikembangkannya Game ChainKiller, yaitu sebuah game real time action RPG Online berbasis Flash untuk memberikan alternatif bermain game yang interaktif dan menarik dengan spesifikasi perangkat keras minimal. Model proses linear sequential model digunakan untuk mengembangkan game secara keseluruhan dan studi kepustakaan digunakan untuk memperkaya wawasan guna mengembangkan game mini yang menarik. Game real time online berbasis Flash ini dapat digunakan dengan mudah dengan spesifikasi perangkat keras minimum.
\end{abstract}

Kata kunci: game, real time, RPG, online, Flash, perangkat keras minimum 


\section{PENDAHULUAN}

Game adalah sebuah sistem formal tertutup yang melibatkan pemain dalam sebuah konflik terstruktur dan menyelesaikan konflik tersebut dengan cara yang berbeda-beda (Tracy Fullerton, 2008, p.43). Definisi yang lebih sederhana menurut Jesse Schell (2008, p.37) adalah bahwa game merupakan sebuah kegiatan pemecahan masalah yang berlandaskan kesenangan.

Game juga salah satu hiburan yang sangat diminati oleh semua kalangan tanpa mengenal batasan umur bahkan jenis kelamin. Semakin banyak saja orang yang gemar bermain game sebagai salah satu sarana hiburan. Game yang tersedianya tentunya beraneka ragam dengan berbagai pilihan genre dan masing-masing game membutuhkan spesifikasi perangkat keras yang berbeda. Tidak jarang game yang digemari memerlukan spesifikasi perangkat keras yang cukup tinggi sementara spesifikasi perangkat keras dimiliki tidak mencukupi sehingga game yang digemari pun tidak bisa dinikmati.

Kondisi inilah yang mungkin melatarbelakangi munculnya berbagai game mini yang menggunakan teknologi Flash di dunia maya. Game seperti ini bisa berupa pop-up dari sebuah website tujuan komersil atau sengaja diproduksi dan bisa diunduh tanpa biaya bagi penggemar game mini. Game mini dengan menggunakan teknologi Flash ini relatif berukuran kecil dan tidak memerlukan spesifikasi perangkat keras yang tinggi sehingga memungkinkan semua kalangan masyarakat bisa menikmatinya.

Inisiatif untuk memungkinkan semua kalangan masyarakat untuk bisa bermain game dengan keterbatasan spesifikasi perangkat keras inilah yang melatarbelakangi dikembangkannya game real time action RPG online berbasis Flash. Materi ini sudah pernah diseminarkan dalam BINUS Information and Communication Technology Conference (ICTC) pada tanggal 16 Agustus 2011.

\section{METODE}

Metode yang digunakan dalam pengembangan sistem ini meliputi metode analisis, metode perancangan, studi kepustakaan, dan metode evaluasi. Metode analisis dilakukan dengan mempelajari minat pemain game serta mengidentifikasi game seperti apa yang digemari sehingga dapat mengembangkan game yang tepat. Metode perancangan dilakukan dengan merancang avatar, senjata, peluru, dunia permaianan, layar panel, sistem permaianan, diagram konteks, diagram nol, class diagram, use case diagram, dan layar. Studi kepustakaan dilakukan dengan membaca berbagai literatur untuk meningkatkan pemahaman mengenai berbagai teori yang dibutuhkan dari merancang dan mengevaluasi serta menyimpulkan hasil evaluasi.

Ada beberapa model proses yang dapat digunakan untuk mengembangkan sistem. Dalam paper ini dibahas satu model yang digunakan untuk mengembangkan sistem pengiriman barang berbasis web pada PT Prabu Expressindo. Linear sequential model disebut juga classic life cycle atau waterfall model di mana model ini menyarankan pendekatan sekuensial linier yang sistematis untuk pengembangan piranti lunak yang dimulai pada tingkatan sistem dengan urutan dari analisis, rancangan, penulisan program, pengujian, dan dukungan.

Model ini meliputi beberapa aktivitas berikut: (1) System/information engineering and modeling - karena piranti lunak selalu merupakan bagian dari suatu sistem yang lebih besar (atau bisnis), pekerjaan dimulai dari menetapkan persyaratan untuk semua elemen sistem dan kemudian mengalokasikan beberapa subset dari persyaratan piranti lunak; (2) Software requirement analysis untuk memahami sifat program yang akan dibangun, software engineer harus memahami domain 
informasi untuk piranti lunak serta fungsi yang diperlukan, perilaku, kinerja, dan antar muka. Persyaratan untuk kedua sistem danpiranti lunak yang didokumentasikan dan di-review dengan pelanggan (customer); (3) design - rancangan piranti lunak sebenarnya adalah sebuah proses bertingkat yang fokus pada empat atribut yang berbeda dan sebuah program, struktur data, arsitektur piranti lunak, representasi piranti lunak, prosedural (algoritma) detil. Proses rancangan menerjemahkan kebutuhan ke representasi dari piranti lunak yang dapat dinilai untuk kualitas sebelum dimulai penulisan program. Seperti persyaratan, rancangan didokumentasi dan menjadi bagian dari konfigurasi piranti lunak; (4) code generation - rancangan harus diterjemahkan ke dalam bentuk yang dapat dibaca oleh mesin (machine-readable form). Penulisan programlah yang menangani tugas ini; (5) testing - proses pengujian fokus pada logika internal software, memastikan bahwa semua persyaratan sudah diuji, dan pada fungsi eksternal, yaitu melakukan pengujian untuk menemukan kesalahan dan memastikan bahwa input yang didefinisikan akan menghasilkan hasil aktual yang sesuai dengan hasil yang dibutuhkan; (6) support - piranti lunak pasti akan mengalami perubahan setelah digunakan sekian lama karena kesalahan telah ditemukan, piranti lunak harus disesuaikan untuk mengakomodasi perubahan dalam lingkungan eksternal (misalnya, perubahan diperlukan karena sistem operasi baru atau peripheral devie), atau karena pelanggan membutuhkan peningkatan fungsional atau kinerja. Berikut adalah gambar linear sequential model (Gambar 1).

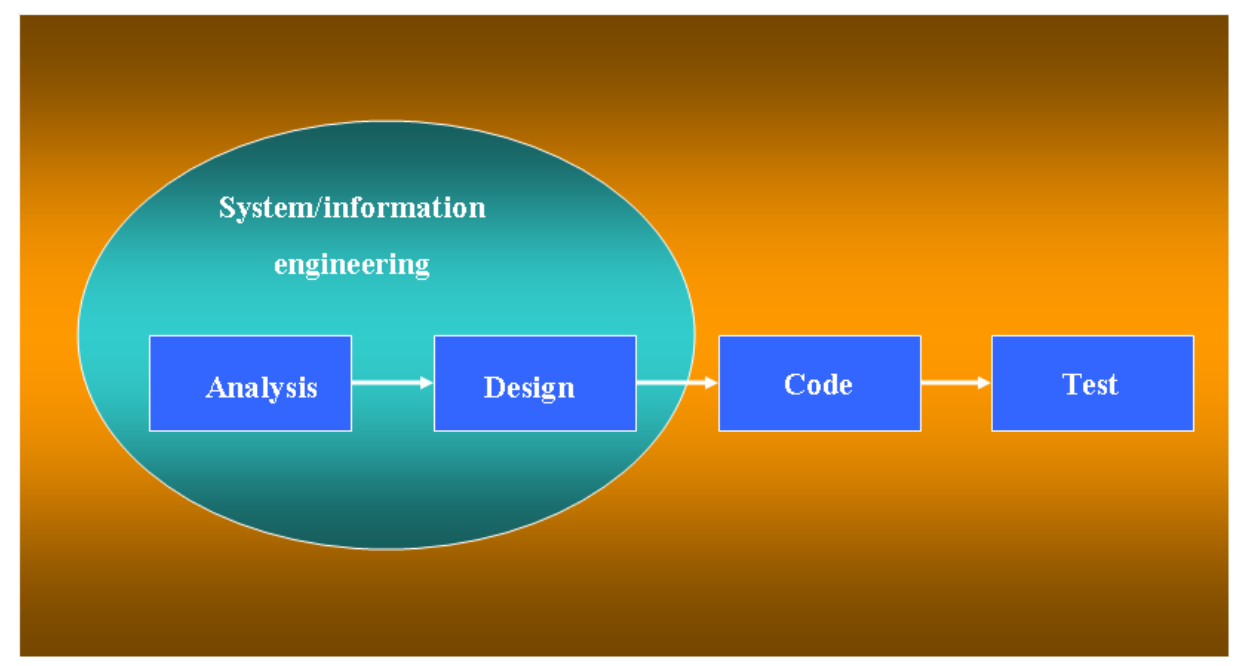

Gambar 1. Linear Sequential Model (Pressman, 2001, p.29).

\section{HASIL DAN PEMBAHASAN}

Sebelum melanjutkan ke perancangan game, simak ulasan tentang game yang dirampung dari berbagai sumber berikut.

\section{Ulasan Game}

Game dibagi menjadi beberapa tipe utama, di antaranya: (1) tabletop game - merupakan istilah umum yang digunakan terhadap board game, card game, dice game, miniature game dan game lainnya yang biasanya dimainkan di atas meja atau permukaan datar lainnya; (2) video game merupakan game elektronik yang melibatkan interaksi dengan tampilan antarmuka (user interface) untuk menghasilkan umpan balik yang berbentuk visual dalam sebuah perangkat video. Video game sendiri sudah terdiri dari arcade game, console game, computer game, mobile game, online game. 


\section{Board Game}

Board game adalah sebuah game di mana potongan-potongan (pieces) diletakkan, dipindahkan, atau digerakkan di atas sebuah "papan” yang merupakan sebuah permukaan yang biasanya berhubungan secara spesifik dengan game yang dimainkan.

Board game dibagi menjadi beberapa kategori. Kategori yang paling umum adalah: (1) abstract strategy game, yaitu game dengan informasi yang jelas, tanpa peluang, dan (biasanya) dimainkan oleh dua orang atau tim. Contohnya Catur dan Go; (2) German-style board game, yaitu sebuah kelas dari tabletop game yang umumnya memiliki peraturan yang sederhana, waktu bermain yang pendek sampai sedang, interaksi antar pemain tingkat tinggi, dan komponen fisik yang menarik. Jenis game ini biasanya menekankan pada strategi, mengurangi tingkat keberuntungan (luck) dan konflik, bertemakan ekonomi daripada militer, dan biasanya tidak mengeliminasi pemain di tengah- tengah permainan. Contohnya Acquire dan Ticket to Ride; (3) roll-and-move, yaitu board game di mana token-token digerakan berdasarkan hasil yang ditunjukan oleh dadu. Contohnya adalah adalah monopoli; (4) war game, yaitu game di mana pemain menempatkan unit militer ke dalam konflik secara langsung dengan pemain lain. Tujuan dari game ini biasanya mengeliminasi lawan atau pencapaian suatu kondisi strategi tertentu. Contohnya Risk dan Axis \& Allies; (4) word game dan puzzle, yaitu game yang membutuhkan kecepatan berpikir, perbendaharaan kata, dan kemampuan bahasa yang baik. Word game biasanya dijadikan sebagai sumber hiburan, namun selain itu, word game juga bisa ditujukan untuk edukasi yang sangat berguna. Contohnya Scrabble.

\section{Online Game}

Online game adalah sebuah game yang dimainkan secara online di jaringan Internet. Game online ini bisa mempertemukan pemain yang satu dengan yang lainnya dalam sebuah dunia maya yang dimiliki game tersebut. Selain itu, pemain juga bisa berinteraksi secara langsung (chat), bertransaksi, dan juga melakukan kegiatan bersama (sesuai dengan fitur yang diberikan oleh masing-masing game).

\section{Time-Keeping System}

Time-keeping sistem adalah sistem pengaturan waktu dalam sebuah game. Ada dua sistem inti dalam time-keeping, yaitu realtime dan turn based. Game real time adalah game yang tidak menggunakan sistem putaran. Pada real-time game pemain melakukan tindakan secara bersamaan dengan lawan, jadi pemain harus mempertimbangkan bahwa lawan mereka juga secara aktif melakukan tugas atau command disaat kita sedang bermain. Pemain ditantang untuk menggunakan manajemen waktu secara tepat. Pada permainan turn-based aliran dan waktu permainan dibagi bagi menjadi tiap bagian yang jelas dan terlihat. Pemain turn-based bisa melihat waktu kapan lawan akan melakukan tindakan sehingga pemain diberikan waktu berpikir untuk melakukan tindakan selanjutnya untuk mengoptimalkan pilihan tindakan. Setelah satu putaran pemain mengambil gilirannya, maka yang bermain adalah pemain berikutnya (lawan), sistem ini berjalan seterusnya berulang-ulang.

Kedua sistem game tersebut memiliki kelebihan masing-masing. Berikut adalah kelebihan masing-masing game tersebut: (1) sistem turn-based: pemain bisa leluasa menggunakan waktu untuk berpikir dalam melakukan tindakan selanjutnya, bukan hanya pada pemain tapi komputer pun bisa memiliki artificial intelegence yang lebih baik karena mempunyai beberapa waktu untuk memproses pergerakannya, pemain lebih mudah dan konsentrasi untuk mengendalikan beberapa unit karakter tanpa harus membagi perhatiannya pada unit yang lain, dan pemain lebih mudah menentukan strateginya dari melihat apa yang akan dilakukan oleh lawan berikutnya; (2) sistem real time: real time game lebih realistis karena tidak menggunakan sistem perputaran giliran, berpikir dan bertindak cepat adalah bagian dari strategi dan sebagai sebuah unsur tantangan tambahan untuk pemain, dan sistem ini tidak memiliki banyak aturan yang dimanipulasi. 


\section{Genre}

Game dikategorikan berdasarkan gameplay-nya. Mengingat adanya sedikit kesamaan pada tiap definisi genre, klasifikasi dari game tidak selalu konsisten atau sistematik. Menurut Marc Saltzman (2000, p.1) ada beberapa genre game, seperti: (1) action game - secara umum lebih bergantung pada koordinasi tangan atau mata dibandingkan cerita atau strategi. Pada umumnya mengandalkan ketangkasan atau reflex; (2) strategy - Game strategi menekankan pada pemikiran dan perencanaan logis. Game strategi cenderung menitikberatkan pada manajemen sumber daya dan waktu yang biasanya didahulukan sebelum respon cepat dan keterlibatan karakter. Perencanaan dan eksekusi taktis sangat penting, dan pencipta game biasanya menempatkan kemampuan pembuatan keputusan dan pengiriman perintah ke tangan pemain; (3) adventure - melibatkan perjalanan dan ekspedisi dari sebuah eksplorasi dan pemecahan teka-teki. Game seperti ini biasanya mempunyai jalan cerita yang linier di mana pemain sebagai protagonis harus menyelesaikan sebuah tujuan utama melewati interaksi karakter dan manipulasi inventaris; (3) role playing game (RPG) - mirip dengan adventure game, tetapi lebih bergantung pada pembangunan dan pengembangan karakter (biasanya disertai dengan statistik pemain), percakapan, dan strategi bertempur dibandingkan pemecahan teka-teki. Dunia fantasi yang luas dan epic quest dengan NPCs (non-player characters) merupakan sesuatu yang umum, dan jalan cerita tidak selalu linier seperti adventure game tradisional. Side quest merupakan sesuatu yang tidak langka bagi RPG; (4) sports - menstimulasi sebuah permainan perorangan atau kelompok dari sudut pandang instruksional atau pemain. Realita merupakan sesuatu yang paling penting, sama seperti ketangkasan dan strategi; (5) simulation atau Sims - secara nyata menstimulasikan sebuah objek atau proses yang dianimasikan maupun tidak. Sebagian besar, sims menempatkan pemain pada sudut pandang 3D orang pertama, atau menciptakan kembali mesin mesin seperti pesawat, tank, helikopter, dan kapal selam.

\section{Game Design}

Menurut Jesse Schell (2008, p.71) ada empat elemen dasar yang membentuk sebuah game, sebagai berikut:

\section{Mekanisme}

Mekanisme adalah prosedur dan aturan dalam sebuah game. Mekanisme mendeskripsikan tujuan dari sebuah game, bagaimana seorang pemain dapat maupun tidak untuk meraih tujuan tersebut, dan apa yang terjadi ketika seorang pemain mencoba untuk meraihnya. Mekanisme terdiri dari enam kategori: (1) dunia - setiap game selalu mengambil tempat dalam sebuah dunia. Dunia ini adalah sebuah "magic circle" dalam sebuah gameplay yang mendefinisikan berbagai macam tempat yang hadir dalam sebuah game, dan bagaimana tempat - tempat tersebut saling berhubungan satu dengan yang lainnya; (2) objek dan atribut - sebuah dunia sudah tentu harus memiliki objek di dalamnya.

Karakter, token, papan skor, segala hal yang dapat dilihat dan dimanipulasi termasuk dalam objek. Atribut adalah informasi yang menjelaskan dan terdapat dalam suatu objek; (3) action - kata kerja dalam sebuah mekanisme game yang berarti segala hal yang dapat dilakukan oleh pemain; (4) peraturan - batasan terhadap hal-hal yang dapat pemain lakukan dalam mekanisme game. Peraturan menentukan dunia, objek, action, konsekuensi dan batasan dari sebuah action, dan tujuan utama; (5) kemampuan (skill) - setiap game mengharuskan pemain untuk melatih kemampuan tertentu. Jika kemampuan pemain setara dengan tingkat kesulitan sebuah game, pemain akan merasa tertantang dan terus bermain; (6) kesempatan atau peluang (chance) - interaksi antara lima mekanisme sebelumnya. Kesempatan adalah bagian terpenting dari sebuah game yang menyenangkan karena kesempatan atau peluang berarti ketidakpastian, dan ketidakpastian berarti kejutan dan kejutan adalah sumber terpenting bagi kesenangan manusia. 


\section{Cerita}

Cerita adalah sebuah urutan event yang menggambarkan sebuah game. Ketika sebuah game memiliki cerita yang ingin diceritakan melalui game tersebut, mekanisme yang dipilih harus tepat untuk memperkuat cerita tersebut dan mampu membiarkan cerita tersebut berkembang.

\section{Estetika}

Estetika adalah yang menentukan bagaimana sebuah game terlihat, terdengar, tercium, dan terasa. Estetika adalah aspek yang sangat penting dalam game design karena berhubungan langsung dengan pengalaman pemain. Pertimbangan estetika adalah bagian yang membuat suatu pengalaman menjadi mengasyikan. Game design yang kuat dan memiliki konsep ilustrasi yang baik akan membuat ide dari sebuah game menjadi lebih jelas untuk semua orang, membiarkan orang-orang melihat dan membayangkan memasuki dunia game tersebut, membuat orang-orang bersemangat untuk memainkan game tersebut.

\section{Teknologi}

Teknologi yang dipilih untuk sebuah game membuat game tersebut dapat melakukan hal-hal tertentu dan melarangnya untuk melakukan hal lain. Teknologi secara esensial adalah media di mana estetika terletak, mekanisme terjadi dan cerita dapat diceritakan.

\section{Perancangan Avatar}

Pada game Chain Killer ini, setelah pemain memasuki salah satu ruangan yang ada, pemain diharuskan untuk memilih salah satu jenis karakter yang telah disediakan untuk dimainkan sebagai avatar mereka. Karakter akan dibedakan berdasarkan tampilan, atribut dan senjata apa saja yang dipakai untuk bertempur nantinya. Berikut ini adalah elemen-elemen status yang akan disertakan dalam karakter:

\section{Health Point}

Health Point (HP) adalah sebuah angka atau bar yang menjadi simbol kehidupan karakter tersebut. Jika HP telah mencapai 0 maka karakter dinyatakan mati.

\section{Defense}

Defense adalah tingkat kekuatan karakter dalam menahan serangan. Dengan adanya defense, serangan musuh tidak akan masuk sepenuhnya ke dalam karakter. Semakin besar defense, semakin besar pula pengurangan serangan musuh yang masuk pada karakter tersebut.

\section{Speed}

Speed merupakan angka yang mempengaruhi kecepatan gerak karakter. Semakin besar nilai speed, semakin cepat pula gerakan karakter dalam menjelajahi map.

\section{Dodge}

Dodge adalah sebuah nilai untuk menyatakan besarnya kemungkinan karakter dapat menghindari serang dan tidak terkena serangan dari musuh sama sekali walupun peluru atau tebasan pedang musuh telah menyentuh gambar karakter tersebut. Semakin besar nilai dodge, semakin kecil pula karakter akan terkena serangan. 


\section{Perancangan Senjata dan Peluru}

Hal-hal yang juga membedakan satu jenis karakter dengan yang lainnya adalah kemampuan karakter dalam membawa berbagai macam senjata, item dan skill. Dalam permainan ini, kami menyediakan berbagai macam bentuk senjata yang dapat dibawa oleh masing-masing karakter. Senjata-senjata akan disediakan dengan beberapa jenis, diantaranya adalah shotgun, handgun, submachinegun, rifle dan didalam masing-masing jenisnya akan dibuat beberapa jenis senjata juga sehingga dapat menambah variasi permainan. Pada dasarnya, senjata jarak jauh maupun dekat memiliki kesamaan elemen yaitu:

\section{Hitrate}

Hitrate dalam permainan ini adalah nilai pada senjata yang mempengaruhi kecepatan senjata tiap detik untuk menyerang. Untuk senjata jenis handgun, Hitrate berfungsi sebagai penghitung lama tembakan dapat digunakan lagi. Semakin besar Hitrate senjata tersebut, semakin banyak serangan yang dapat dilancarkan oleh senjata tersebut tiap detiknya.

\section{Damage}

Adalah nilai yang akan ditimbulkan pada musuh atau objek apabila serangan senjata tersebut mengenainya. Semakin besar nilainya maka akan semakin besar pula pengurangan darah yang diterima oleh objek yang terkena serangan tersebut.

\section{Range}

Adalah nilai dari jarak serang yang dapat dilakukan oleh senjata tersebut. Semakin besar nilainya maka jarak serang senjata tersebut juga akan semakin jauh.

Permainan yang dirancang merupakan permainan yang berbasis perang antar pemain sehingga setiap avatar pemain memiliki senjatanya masing-masing. Senjata yang dirancang adalah senjata jarak jauh dengan peluru sebagai media penyerangannya. Peluru dalam rancangan permainan ini, dirancang dengan menggunakan Adobe Photoshop sebagai pembentuk gambar dan Adobe Flash sebagai pembuat animasi pergerakannya. Dalam satu movieclip peluru tersebut terancang ada 2 movieclip lagi di dalamnya yaitu movieclip untuk peluru saat bergerak dan saat menabrak tembok atau rintanganrintangan lainnya dalam satu peta permainan yang digunakan.

\section{Perancangan Permainan}

Seting peta yang digunakan dalam permainan nantinya akan disediakan dalam beberapa variasi dan pembuat ruangan lah yang akan menentukan lokasi peta mana yang akan mereka gunakan untuk bermain. Pada dasarnya semua peta dalam permainan ini memiliki ciri khas yang sama, yaitu terdapat dua markas, yaitu markas tim 1 dan tim 2, markas inilah yang menjadi tolok ukur kemenangan dari masing-masing tim tersebut. Selain itu, di dalam peta tersebut juga terdapat berbagai macam objek yang berperan sebagai penghalang seperti tembok, kotak, mobil dan objek-objek ini tidak dapat dilewati pemain sehingga peta terlihat lebih nyata batasan-batasannya. Selain kedua objek tersebut, terdapat juga gambar rerumputan, lantai, atau semacamnya sebagai gambar dasar dari peta ini.

\section{Perancangan Layar Panel}

Layar panel adalah layar yang muncul saat permainan telah dimulai. Layar ini berfungsi sebagai pemberi informasi kepada pemain tentang keadaan permainan dan keadaan avatar yang 
sedang pemain jalankan. Tampilan panel tersebut kami rancang untuk permainan ini selain karena fungsinya yang vital bagi pemain dan jalannya permainan, juga karena layar tersebut sudah merupakan standar tidak tertulis pada semua permainan komputer hanya saja apa yang ditampilkan dan diinformasikan kepada pemain berbeda-beda antara satu game dengan game yang lainnya. Adapun rancangan awal layar panel untuk permainan kami adalah seperti ini (Game 2):

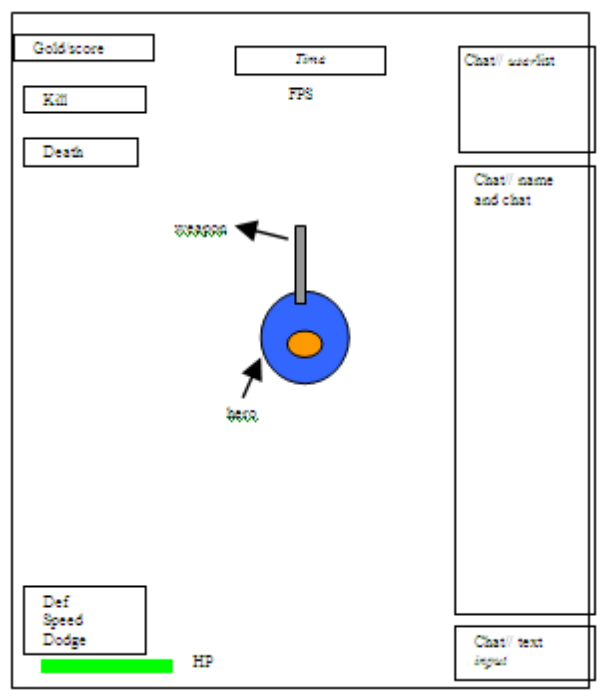

Gambar 2. Rancangan Layar Panel

\section{Rancangan Permainan}

Berikut beberapa bagan rancangan permainan (Gambar 3 dan 4).

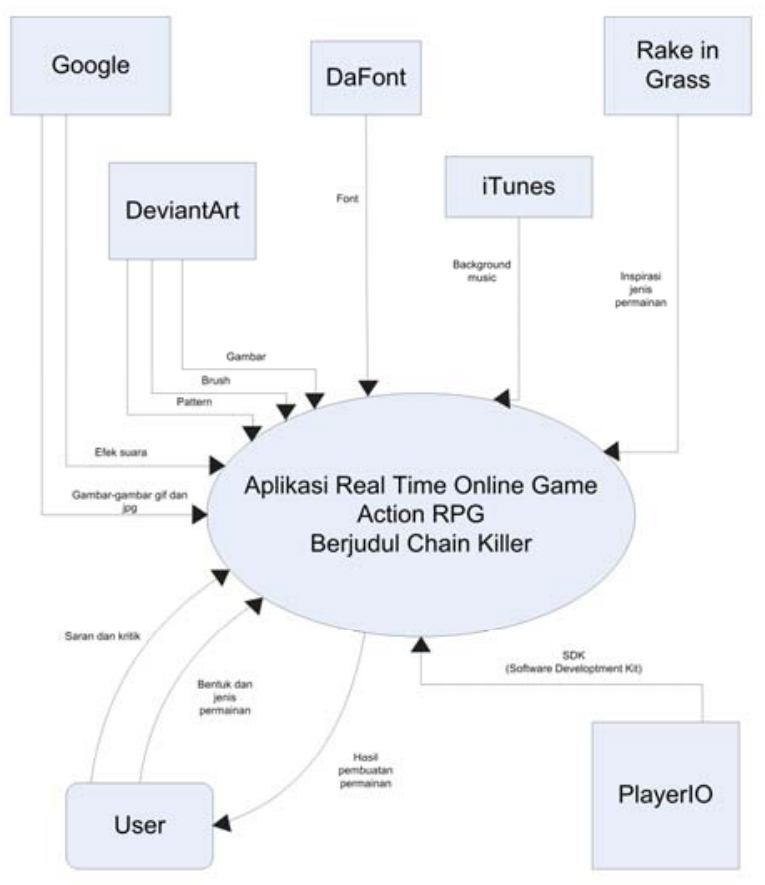

Gambar 3. Diagram konteks. 


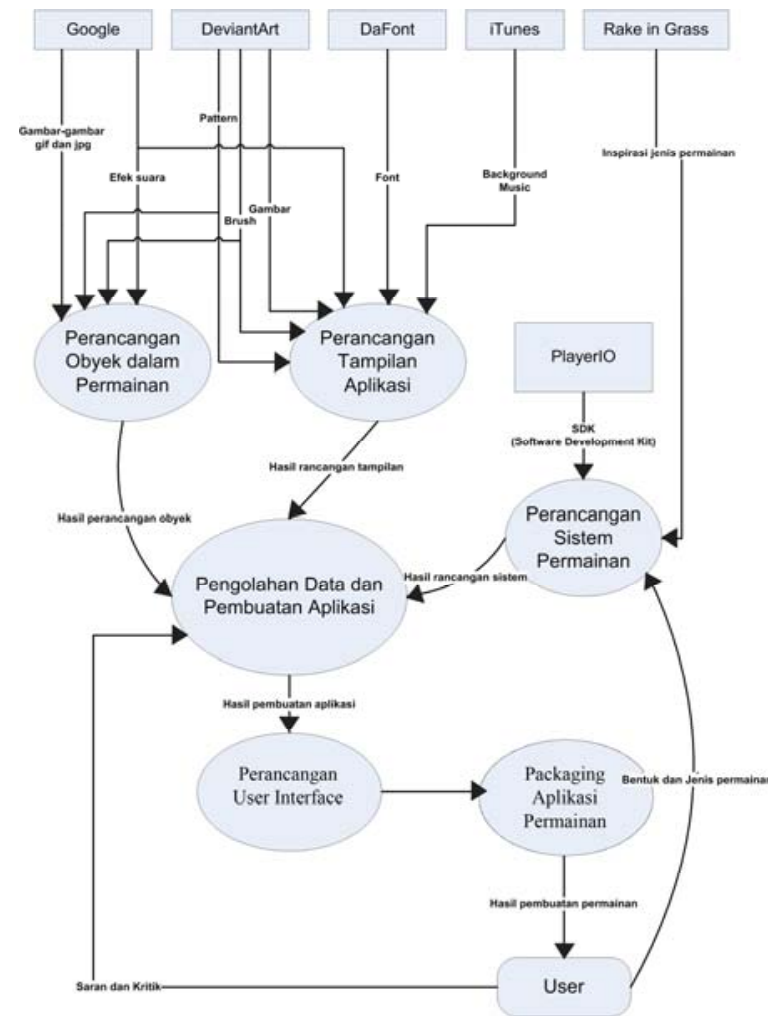

Gambar 4. Diagram nol.

Dari hasil rancangan dibuatlah game dengan tampilan yang seperti pada beberapa screenshoot berikut ini (Gambar 5 dan 6).

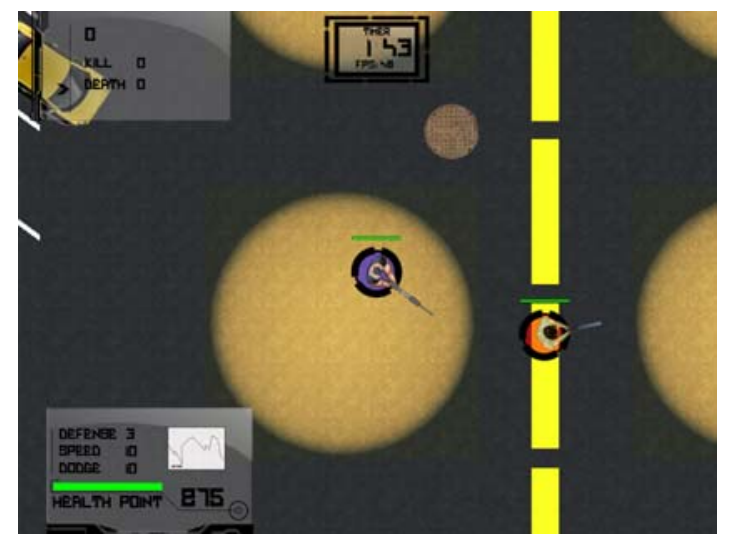

Gambar 5. Tampilan layar saat bertemu dengan user lain.

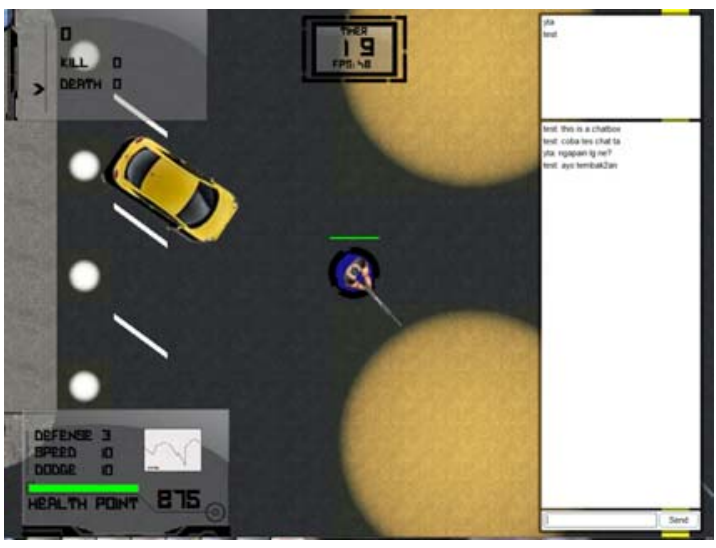

Gambar 6. Tampilan layar dengan chat box.

Spesifikasi perangkat keras yang dibutuhkan Prosesor AMD Athlon X2 $3800+2.0$ Ghz, Hard disk space \pm 500MB, Memory (RAM) 3GB, Monitor, Keyboard, dan Mouse 


\section{Evaluasi}

Evaluasi secara mandiri dilakukan dengan membandingkan game ChainKiller yang sudah berhasil dikembangkan dibandingkan kaidah aturan emas di mana hasil evaluasi menunjukkan bahwa game yang telah dikembangkan konsisten, beberapa shortcut disediakan pada gambar untuk memudahkan mengenal fungsinya, sistem akan mengirimkan umpan balik kepada setiap aksi pemain sehingga pemain yang bersangkutan akan mendapatkan status kondisi yang sedang berlangsung sesuai dengan aksinya, pemain dapat mengetahui keadaan akhir dari status kondisi yang sedang berlangsung, pesan kesalahan pada input, pembatalan aksi yang telah dilakukan dengan mudah, pemain diberi kebebasan untuk bernavigasi tanpa urutan yang ditentukan, dan penggunaan gambar maupun link di dalam game ChainKiller dibuat sesederhana mungkin sehingga pemain mampu mengenal fungsi dari link dan gambar yang dimaksud. Hasil evaluasi ini menunjukkan bahwa game yang dikembangkan memenuhi kaidah aturan emas.

Evaluasi dari segi Game Balancing juga dilakukan. Adil, game asimetris dilihat dari keunggulan dan kelemahan tiap karakter yang berbeda-beda. Tantangan dibandingkan sukses, game telah mempertimbangkan perbandingan antara tantangan dan kesuksesan yang terlihat dari dibentuknya sebuah basecamp dari tiap pemain yang harus dihancurkan jika ingin memenangkan permainan. Pilihan yang berati, aturan ini bisa dirasakan saat user akan menghancurkan basecamp musuh, apakah user akan langsung menuju basecamp lawan dan menghancurkannya tetapi beresiko akan terbunuh oleh user lawan atau akan bermain aman dengan membunuh karakter lawan dahulu barulah menghancurkan basecamp-nya. Kemampuan dibandingkan kesempatan, game telah diseimbangkan antara kemampuan dan kesempatan, kemampuan diperlukan saat akan menghancurkan basecamp lawan yang juga bisa menembak dan memberikan demage sedangkan kesempatan dilihat dari kemampuan musuh yang tidak bisa kita tebak apakah musuh tersebut telah terlatih atau tidak dalam memainkan game ini. Permainan otak dibandingkan kecepatan tangan, permainan otak dapat dirasakan saat user mengatur strategi untuk menghancurkan basecamp musuh tanpa terkena tembakan dari basecamp yang cukup menguras banyak tenaga sedangkan kecepatan tangan lebih bisa dirasakan saat bertemu dengan lawan dan berusaha untuk menghindar ataupun membunuhnya. Kompetisi dibandingkan kerjasama, dapat dilihat dari interaksi seorang pemain dengan musuhnya yang saling berjuang untuk bertahan hidup, sedangkan kerjasama dirasakan saat mengatur serangan bersama dengan pemain lain yang tergabung dalam satu tim. Durasi, jika user sudah menguasai betul konfigurasi dan sistem dari game ini, maka mereka bisa dengan cepat mengalahkan musuh.

Hadiah, saat seorang pemain membunuh salah satu musuh maka jumlah Kill akan bertambah atau jika pemain telah terbunuh maka jumlah Death akan bertambah. Selain itu jika user telah menghancurkan basecamp dari user lain maka permainan akan selesai dan dimenangkannya. Hukuman, diterapkan dalam pengaturan respawn di mana ketika seorang pemain terbunuh maka akan terdapat waktu tunda 5 detik sebelum mereka bisa bermain kembali. Kebebasan dibandingkan keterbatasan, pemain diberi kebebasan untuk mengelilingi map dengan bebas, tetapi hanya sebatas map itu saja dan terdapat beberapa bagian yang memang tidak bisa dilalui oleh pemain. Sederhana dibandingkan kompleks, game yang berunsur emergent complexity, karena kompleksitasnya relatif. Jika kita bertemu dengan musuh yang sudah menguasai betul permainan ini, maka untuk memenangkan game akan terasa berat. Detil dibandingkan imajinasi, game ini telah diberikan detil detil dari masing masing map, yaitu apa saja yang bisa terdapat dalam sebuah dunia tersebut, misalnya dengan objek-objek yang tidak bisa dilalui oleh pemain. Dengan objek-objek ini pemain dibiarkan untuk berimajinasi tentang sebuah tempat yang telah diberikan dan menjadikan objek-objek ini sebagai tempat yang tepat untuk bersembunyi dari serangan lawan.

Selain itu evaluasi juga dilakukan dengan meminta kepada 14 orang responden untuk mencoba game tersebut dan hasil menunjukkan bahwa game mudah dimainkan, menarik, fitur cukup lengkap, tidak mengalami kendala dengan konfigurasi tombol, dan secara kesuluruhan game menarik. 


\section{PENUTUP}

Game ini telah memenuhi kaidah aturan emas dan game balancing. Game online berbasis flash menarik dan mudah digunakan serta ini dapat dimainkan pada computer dengan spesifikasi perangkat keras yang tidak terlalu tinggi.

Berikut ada saran untuk pengembangan game lebih lanjut: penambahan karakter dan pilihan senjata sehingga semakin banyak ragam unsur permainan dan penambahan keamanan jaringan untuk menangkal penggunaan cheat oleh pemain.

\section{DAFTAR PUSTAKA}

Fullerton, Tracy. Game Design Workshop (second edition). Massachusetts: Morgan Kaufmann Publisher.

Pressman, Roger S. (2001). Software Engineering: A Practitioner's Approach (edisi ke-5). NewYork: McGraw-Hill.

Saltzman, Marc. (2000). Game Design Secrets of the Sages (second edition). Indiana: Brady Games.

Schell, Jesse. (2008). The Art Of Game Design. Massachusetts: Morgan Kaufmann Publisher. 